\title{
European integration as a threat to social security: Another source of Euroscepticism?
}

\author{
Sharon Baute \\ Institute of Social and Political Opinion Research, University of Leuven, Belgium \\ Bart Meuleman \\ Institute of Social and Political Opinion Research, University of Leuven, Belgium \\ Koen Abts \\ Tilburg School of Social and Behavioural Sciences, Tilburg University, The Netherlands \\ Marc Swyngedouw \\ Institute of Social and Political Opinion Research, University of Leuven, Belgium
}

\section{Accepted for publication in European Union Politics}

\author{
Corresponding author: \\ Sharon Baute \\ University of Leuven \\ Institute for Social and Political Opinion Research \\ Parkstraat 45 box 3601 \\ 3000 Leuven \\ Belgium \\ sharon.baute@kuleuven.be
}




\section{European integration as a threat to social security: Another source of Euroscepticism?}

\footnotetext{
Abstract

This study investigates whether citizens' concerns about the EU's impact on social security are a distinct source of Euroscepticism. By analysing data from the European Values Study 2008, we show that citizens differentiate between domain-specific fears about European integration (i.e. about social security, national sovereignty, culture, payments and jobs), meaning that they cannot be reduced completely to a general fear about European integration. Furthermore, socioeconomic determinants and ideological position are more important in explaining citizens' fear about the EU's impact on social security than in explaining their generalised fear of European integration. In countries with higher social spending, citizens are more fearful of European integration in general, however, social spending does not affect fears about social security more strongly than it affects other EU-related fears.
} 


\section{Introduction}

According to Hooghe and Marks (2008), the 'permissive consensus' regarding European integration has been replaced by 'constraining dissensus' as European institutions and policies have become more visible, politicized and contested. Similarly, others argue that 'as the nature of the European project is becoming more diverse, so are the reasons to oppose it' (van Elsas and van der Brug, 2015: 197). As a result, concerns about European integration and its consequences for member states and citizens have become apparent in different areas (Grauel et al., 2013). For example, fear over a loss of political influence has a clearly distinct logic and nature compared with concerns that European integration threatens national identity and culture (McLaren, 2004). Furthermore, the Eastern enlargements and the recent bailout operations have fuelled economic anxieties about increasing costs (Bechtel et al., 2014; Karp and Bowler, 2006), while internal market policies have fuelled worries about relocating jobs to other countries (Bernaciak, 2014).

This study focusses on citizens' concerns about a loss of social security resulting from European integration. Whereas economic integration was deemed the driving force for rising welfare standards for a long time, concerns that European integration threatens welfare and social protection have recently been surfacing (Eichenberg and Dalton, 2007). Citizens can perceive the interference of the EU in the social policy area either as 
a threat, leading to a loss of social security, or as an opportunity, reinforcing and extending national welfare arrangements. Importantly, fears about a loss of social security diminish support for joint European decision-making concerning social policy (Mau, 2005) and for European integration in general (Brinegar and Jolly, 2005).

Nevertheless, the perceived impact of the EU on social security has received little previous attention in empirical research (Beaudonnet, 2012; Cautrès, 2012; Ray, 2004). In addition, studies focusing on concerns about social security analyse it in isolation from citizens' concerns about the EU's impact on other domains of society, such as national sovereignty, national identity, financial contributions and employment. The differences and commonalities between these sources of Euroscepticism have not previously been investigated. As a result, knowledge about how strongly the social dimension of Euroscepticism is related to other domain-specific concerns about European integration is lacking. Accordingly, in this article we investigate if fear concerning a loss of social security resulting from European integration can be perceived as a specific fear that is peculiar to the social aspects of the EU, or whether it is merely a reflection of a general anxiety about European integration sui generis. Second, we examine whether fears that European integration endangers the existing social security level are affected differently by social-structural position, ideological disposition and national context compared with other EU-related fears (referring to national sovereignty, identity, financial contributions 
and jobs). To answer these questions empirically, we analyse cross-national data from the European Values Study (2008) by means of multilevel structural equation modelling. Our study illustrates that fear about social security cannot be reduced completely to a general fear of European integration, and is related to particular structural and ideological determinants.

\section{European integration as a threat: Different sources of Euroscepticism?}

Citizens may perceive European integration as a threatening process in its entirety, leading to a generalised fear of integration. However, the expansion of the European project has made the grounds for opposing European integration more diverse. Various sources of Euroscepticism are discussed in the literature, each related to a particular threat that the EU poses. These threats centre on the issues of national sovereignty, cultural identity, financial contributions, jobs and social security.

One basis for Euroscepticism relates to the perceived threat to national sovereignty (Sørensen, 2007). It originates from opposition towards the very idea of European political integration, for example emanating from calls for a political union based on the European federal state (Cohn-Bendit and Verhofstadt, 2012). Public support for further political integration was already low in the 1990s, and in many policy areas Europeans 
still prefer national sovereignty to European decision-making (European Commission, 1997, 2011).

Euroscepticism may also be rooted in perceptions that European integration challenges national identity and culture (Carey, 2002). A substantial proportion of European citizens fear that the process of European integration is eroding everyday practices, lifestyles and national culture (McLaren, 2004). It has been shown that cultural concerns were an important underlying element in the 'No' vote in the Dutch referendum of 2005 (Lubbers, 2008).

In addition, Euroscepticism can also stem from cost-benefit calculations regarding the financial consequences of European integration. In many - especially net-contributing countries, concerns about national financial contributions to the EU budget are prevalent (Leconte, 2010). Enlargement of the EU, and the recent Eurozone crisis, increased the salience of the financial consequences of European integration, for instance in terms of changing incoming subsidies and the budget contributions of member states (Hobolt, 2015; Karp and Bowler, 2006).

A further source of Euroscepticism relates to the threat that the EU poses to the labour market and in particular to jobs (Grauel et al., 2013). As a result of the internal market, citizens might feel that job prospects and earnings are negatively affected by posted 
workers (i.e. employees who are sent by their employer to carry out a service in another EU Member State on a temporary basis) and the relocation of jobs to member states where production is cheaper. In the context of the EU enlargements of 2004 and 2007, concerns about regime competition and social dumping were translated into restrictions on the free movement of Eastern European workers.

Turning to the focal point of this study, Euroscepticism can also stem from perceived threats to social security (Beaudonnet, 2012). In this regard, Sørensen (2007: 140) argues that 'social Euroscepticism' - defined as scepticism towards the EU's social engagement - was important to explain differing support for the EU Constitution in 2005. One in four Europeans who opposed the Constitution mentioned that it was not social enough and too liberal (Sørensen, 2007). The view that the EU has a negative effect on national social security systems and should promote a Social Europe (Delors and Fernandes, 2013) has gained currency in European public opinion. For example, one in two citizens worries about a loss of social benefits resulting from European integration and 43 percent of Europeans believe that fighting poverty and social exclusion should be the top priority for the EU (European Commission, 2007). Social Euroscepticism may stem from different facets of the European integration process. First, increased intra-EU immigration is assumed to facilitate 'welfare tourism' (Fóti, 2015), arousing fears about adverse effects on the sustainability of social protection systems. Second, the EU is 
associated with a 'race to the bottom' in social standards, as the internal market constrains the ability of governments to sustain generous systems of social protection (Kvist, 2004). Third, the Economic and Monetary Union (EMU) and its convergence criteria concerning the inflation rate, public finances, interest rates and exchange rate stability are seen as significant interference by the EU in the area of domestic redistribution (Eichenberg and Dalton, 2007). Following the Euro crisis, the EU - which supervises budgetary discipline - has become increasingly associated with cuts in public spending and reduced social protection (Leconte, 2010). Lastly, even active social policymaking at the European level can produce concerns about the level of social protection. Because of the diversity of social protection schemes in Europe, fear of convergence towards the 'lowest common denominator' that will retrench generous welfare states has gained ground (Scharpf, 2010).

It is clear that fear from European integration can have different substantive roots. Yet it is unknown to what extent domain-specific fears, such as concerns about a loss of social security, are truly distinct phenomena or are parts of an over-arching generalised fear. On the one hand, citizens' perceptions of the impact of European integration on different domains might deviate from one another, because citizens pay more attention to issues they find important. On the other hand, one could assume that citizens are 
relatively uninformed about European integration and fail to differentiate between various types of EU-related threats.

\section{Explaining citizens' fear of European integration concerning social security}

If citizens' fear of a loss of social security is a truly distinct source of Euroscepticism, this should be reflected in the specificity of its causal antecedents. If we can identify predictors that are particularly relevant to specific concerns about social security, then the assumption that these concerns are merely reflections of a generalised fear of European integration can be rejected. A variety of theoretical approaches - including self-interest, cognitive mobilization, cue-taking and identity approaches (Abts et al., 2009; Hobolt, 2012) - have been put forward to explain EU attitudes.

\section{Individual-level explanations: Utilitarian interest and ideological orientation}

To explain individual differences in citizens' fear about a loss of social security, we distinguish two complementary approaches: the utilitarian approach and the ideological approach, which focuses on preferences regarding government intervention and income redistribution.

The utilitarian approach relates Euroscepticism to self-interest and makes assumptions about what social categories are more likely to gain or lose from European integration 
(e.g. Anderson and Reichert, 1996; Gabel, 1998). It is expected that those with higher levels of income, education and occupation skills can benefit more from the new opportunities and are better able to succeed in an integrated European market, since they are more mobile and flexibly employed. European integration should prove more threatening to individuals with lower levels of financial and human capital, because their life chances, which were traditionally protected by national boundaries, are being reduced (Kriesi et al., 2008). Studies show that citizens with lower socioeconomic status and those dependent on the welfare state have more reservations about European integration in general (Beaudonnet, 2015; Mau, 2005).

In line with this reasoning, we can expect that citizens with lower socio-economic status are especially concerned about the EU's impact on social security, because their life chances are determined to a larger extent by national welfare provisions than those of higher socioeconomic status groups (Gerhards et al., 2016). In particular to welfare beneficiaries, European integration may represent a threat to social security as it might change the status quo of redistributive mechanisms (Beaudonnet, 2015). For instance, the granting of access to social security systems for EU citizens, the induced austerity policies and spending cuts of the EMU, and pressures of social policy convergence might fuel fear of a loss of social security that is disproportionally stronger among individuals with lower socioeconomic status. Although these citizens have also benefited from the 
EU's positive market-correcting policies, such as regulations in the field of health and safety at work (Falkner, 2010), overall, we could expect that they perceive the EU's impact in the sphere of social protection more negatively. Because citizens' structural position in society influences their dependence on social security, we expect that on top of the effect of socioeconomic status on citizens' generalised fear, socio-economic status has an additional negative effect on concerns about the EU's impact on social security.

Concerns about European integration do not only vary with regard to self-interest calculations, but are also rooted in ideological perspectives. Political conflict over European integration is related to a left/right dimension concerning state regulation and social redistribution (Hooghe and Marks, 1999). Left-wing parties view European integration as an amplifier of globalization, inducing rising inequality, and are preoccupied with the effects of integration on workers and welfare systems (Bertoncini and Koenig, 2014). Accordingly, empirical studies show that voters' preferences for active government in the socioeconomic sphere are an important predictor of Euroscepticism (Brinegar \& Jolly, 2005; Garry and Tilley, 2015; Van Elsas and Van der Brug, 2015). Since European policy has mainly been focusing on the creation of a single market, we expect that citizens who are strongly in favour of government intervention and income redistribution experience European integration as more threatening. In 
addition, those who prefer higher levels of government intervention, social regulations and redistribution are expected to be particularly fearful of the EU's impact on social protection, because the preservation of social security is salient to them (Føllesdal et al., 2007). Empirical studies show that left-wing citizens evaluate the EU's impact on social security more negatively than right-wing citizens (Cautrès, 2012; Van Elsas and Van der Brug, 2015). Given that left-wing respondents are susceptible to social security related concerns, we expect that preferences regarding government responsibility and income redistribution are more powerful in explaining citizens' concerns about the EU's impact on social security in comparison with other types of fear about European integration.

\section{Explaining cross-national differences}

Various studies have evidenced that contextual factors shape attitudes towards European integration (Brinegar and Jolly, 2005; Eichenberg and Dalton, 2007). Most of the literature on cross-national variation in attitudes towards the EU is based on utilitarian appraisals, assuming that not only individuals, but also entire countries can win or lose from European integration. Four explanatory factors are relevant in this respect: the level of welfare provisions, national economic conditions, financial transfers received from the EU and intra-European immigration.

European integration affects national welfare states in different ways and to different degrees (Scharpf, 2010). In the most-developed welfare states, the free market 
competition rules exert strong pressures to lower the burden of social security. Accordingly, concerns about European integration in the most comprehensive welfare states particularly relate to the robustness or vulnerability of their welfare model against these pressures (Andersen, 2004). Hereby, a race to the bottom and the deterioration of the quality of social services is feared. By contrast, in welfare states where coverage is weaker, the expected impact of integration is less negative. Moreover, citizens might hope that social standards and social protection levels will improve as a result of the EU's interference in welfare issues (Burgoon, 2009; Mau, 2005). In this regard, empirical studies show that in countries with higher levels of social spending, citizens have more reservations about the European project (Balestrini et al., 2010; Sanchez-Cuenca, 2000). In addition, citizens in more-advanced welfare states evaluate the EU's impact on social security more negatively and are less willing to transfer social competences to the European level (Gerhards et al., 2016; Mau, 2005; Ray, 2004).

Second, citizens' evaluations of European integration are based on national economic conditions (Anderson and Kaltenhaler, 1996). If the national economy is performing strongly, citizens tend to believe that supranational politics guarantee or reinforce prosperity in the country (Netjes, 2004). Conversely, Euroscepticism has increased most strongly in the member states most affected by the recent economic crisis (Foster and Frieden, 2017; Serricchio et al., 2013). We expect that economic conditions are 
especially important for citizens' confidence about the maintenance of social protection levels, as poor economic conditions may trigger fears about cuts in social spending.

Financial transfers within the EU are another important source of potential country-level benefits from European integration and vary considerably across member states. Citizens living in countries that benefit more from transfers show greater support for European integration overall (Anderson and Reichert, 1996; Brinegar and Jolly, 2005). We assume that EU transfers are particularly important in explaining citizens' assessments of how the EU is affecting social welfare. A large proportion of these transfers are distributed through the structural and investment funds, reducing regional disparities in income, employment, investment and growth (Anderson, 1995), and through the agricultural fund of the Common Agricultural Policy. As financial transfers are often used for programmes serving welfare functions, we expect that higher national benefits reduce negative evaluations regarding the EU's impact on social protection.

Lastly, concerns about European integration are often linked to intra-EU immigration facilitated by the free movement of individuals (Fóti, 2015). Significant differences in the number of EU foreigners exist between countries, with east to west and south to north movements being most prevalent (Eurofound, 2014). Although citizens living in countries with high intra-EU mobility rates might be more concerned about European integration in general (Toshkov and Kortenska, 2015), we expect that intra-EU 
immigration will increase concerns about the EU's impact on social protection in the first place. Increased migration is believed to put additional pressure on welfare benefits and social services in host countries (Kvist, 2004). The assumption of so-called welfare tourism, namely that EU migrants are attracted by more generous welfare benefits in destination countries, only reinforces this belief. Where the proportion of EUimmigrants is larger, citizens might thus be more likely to think that European integration is detrimental to their welfare state.

Compared with citizens' general fear of European integration, we expect that member states' level of welfare provisions, economic conditions, net EU-transfers and intra-EU immigration are especially indicative of the perceived EU impact on social security. These country characteristics either provide the lens through which citizens will evaluate the EU's impact on social security (i.e. level of national welfare provisions, economic conditions) or directly relate to EU-level welfare assistance and its beneficiaries (i.e. EU net-transfers, intra-EU immigration).

\section{Hypotheses}

Table 1 summarizes the hypotheses that are derived from the theoretical arguments set out above. We expect that the individual-level and country-level factors mentioned influence citizens' generalised fear of European integration, but also that they have an additional influence on citizens' fear concerning a loss of social security. ${ }^{1}$ 
[Table 1]

\section{Data and methods}

Data: We use data from the European Values Study 2008, including all EU-28 countries. ${ }^{2}$ Based on probability-based samples of the adult population, face-to-face interviews were conducted (computer assisted or pencil and paper), except in Finland (internet panel) and in Sweden (postal survey). National response rates range from 24.38 percent in the United Kingdom to 87.23 percent in Finland.

\section{Variables}

Individual level: The different types of fears of European integration are measured by the following question: 'Some people may have fears about the building of the European Union. For each, tell me if you personally are currently afraid of': 'The loss of social security', 'The loss of national identity and culture', 'Our country paying more and more to the European Union', 'A loss of power in the world for [country]' and 'The loss of jobs in [country]'. Responses were recorded on a 10-point scale ranging from 'Very much afraid' (1) to 'Not afraid at all' (10) and were recoded so that higher scores indicate higher levels of fear. The latent variable 'generalised fear of European integration' underlies all five items. 
To test the hypotheses of economic self-interest, different indicators of socioeconomic status are included. Educational level is measured by the respondents' highest level of education completed (lower-secondary, upper-secondary and tertiary education). Income is expressed in quartiles of equivalised household income (including wages, salaries, pensions and other incomes) within each country. To equivalise the income, the harmonised monthly household income was divided by the number of people living in the household, where each additional adult counts for 0.7 and each child for 0.5 units. Missing items are included in a separate category (25.09 percent). Employment status is included as a variable with five categories: paid employment, retired, student, unemployed or disabled, and others (military service, homemaker, etc.). The EVS measures the use of welfare benefits by the respondent's or his/her partner's dependence on means-tested welfare benefits during the last five years prior. These benefits do not include entitlements to unemployment or disability benefits, or pensions. However, the accurate measurement of employment status is complementary in distinguishing specific welfare beneficiaries.

Ideology is assessed using two items reflecting preferences towards economic individualism versus social equality. First, pro-state responsibility attitudes are measured by respondents' self-positioning on a 10-point scale ranging from 'Individuals should take more responsibility for providing for themselves' to 'The state should take 
more responsibility to ensure that everyone is provided for'. Second, pro-income redistribution attitudes are measured by respondents' self-positioning on a 10-point scale ranging from 'Incomes should be made more equal' to 'There should be greater incentives for individual effort'. Responses were recoded so that higher scores indicate pro-state responsibility and pro-income redistribution attitudes.

We control for age and gender, migration background (dummy for citizens with at least one parent born outside the country of residence) and anti-immigrant attitudes (5-item scale) because we expect them to affect citizens' fear of European integration, although they are not the focus of this study. Anti-immigrant attitudes are captured by responses on opposite statements (1-10 scale), with higher scores indicating stronger agreement with the statements 'Immigrants take jobs away from natives in a country', 'A country's cultural life is undermined by immigrants', 'Immigrants make crime problems worse', 'Immigrants are a strain on a country's welfare system' and 'In the future the proportion of immigrants will become a threat to society'.

Country level: The extensiveness of social welfare provisions is measured by net spending on social protection benefits as a percentage of GDP (Eurostat indicator: spr_net_ben). Missing data for France and Poland was imputed by figures for the nearest available year (2010 instead of 2008). Although more accurate indicators of welfare generosity exist (Scruggs et al., 2014), the social spending measure is the best 
option available for all EU-28 countries. National economic conditions are assessed by the annual unemployment rate (Eurostat code: une_rt_a). Financial transfers are measured by the member states' net transfers received from the EU as a percentage of their gross national income (see calculations of operating budgetary balances: European Commission, 2015). A negative net transfer means that the country receives less payment from the EU than it contributes and that the country is thus a net contributor, whereas a positive percentage means that the country is a net beneficiary of the EU's budget. Intra-EU immigration is measured by the number of EU immigrants per 1000 inhabitants (calculations based on Eurostat data: migr_pop1ctz).

Descriptive statistics of individual and country-level variables are provided in the Online appendix.

\section{Statistical modelling}

We perform multilevel analyses to take into account the hierarchical data structure and to estimate individual-level and country-level effects simultaneously. Between 4.3 percent (loss of national identity and culture) and 9.8 percent (loss of jobs) of the variance of the specific fears is attributable to country-level differences, indicating that multilevel analysis is meaningful. Our methodological strategy consists of multiple stages. First, to identify to what extent EU-related fears are distinct from one another, we conduct multilevel confirmatory factor analysis (MLCFA). This factor-analytic model 
makes a distinction between (1) a latent variable that captures the shared variance of domain-specific fears, i.e. the generalised fear; and (2) the unique variance of the indicators, i.e. the domain-specific fears. Second, to analyse to what extent the determinants of fear about a loss of social security are domain-specific, we rely on multilevel structural equation models (MLSEM). The advantage of MLSEM over standard multilevel regression modelling is that it allows estimating 'generalised fear' as a latent variable. Figure 1 depicts the general effects by the arrows from the independent variables to the latent factor 'fear of European integration' at the individual and at the country level. The domain-specific effects at both levels are shown by the arrows pointing to 'social security'. These specific effects represent how certain predictors affect social fears differently compared to generalised fear. We do not observe multicollinearity problems, as all correlations between independent variables range between 0.01 and 0.69 .

[Figure 1]

Because the number of higher-level units in our dataset ( 28 countries) is relatively small (Meuleman and Billiet, 2009), we make use of Bayesian estimation. The Bayesian 
approach yields credibility intervals that have better coverage than maximum likelihood based confidence intervals (Hox et al., 2012). To obtain estimates of the posterior distribution, the Gibbs sampler is used (two chains with maximum of 50,000 iterations). To monitor convergence, we used the Gelman-Rubin convergence criterion ${ }^{3}$ with 0.01 as the cut-off criterion. Furthermore, we inspected trace plots visually to check the convergence of the chains and the stability of the estimates. Because the Bayesian approach provides little information about the global model fit, we additionally reestimated all models using robust maximum likelihood estimation to obtain fit indices. All the analyses were performed using Mplus software version 7.3.

\section{Results}

Are fears of European integration domain-specific?

Europeans turn out to be somewhat concerned about the EU's impact on social security, as they score on average 6.14 on a scale from 0 to 10 . Overall, these concerns rank third, preceded by fears regarding a loss of jobs and increasing national contributions to the EU. Details on the domain-specific fears in each country is provided in the Online appendix. 
The (dis)similarities between the five domain-specific fears are investigated using MLCFA (see Figure 2). At both levels, the factor structure consists of a single underlying latent construct - generalised 'fear of European integration' - that is measured by the five domain-specific fears. To test the equality of factor structures at the individual level and the country level (cross-level isomorphism), we constrained the factor loadings to be equal across levels. Modification indices suggested including an error correlation between fear over the loss of national identity and culture, and fear about a loss of jobs $(-0.232 ; p<0.001)$. This negative residual covariance makes sense, because cultural threat and the threat to jobs are substantively less associated with each other than the other EU-related fears. The adapted model has a good fit: $\chi^{2}=231.962$, the RMSEA equals 0.020 and both the CFI (0.979) and TLI (0.968) are sufficiently close to 1 . The equality of factor loadings across levels indicates that the latent construct 'generalised fear of European integration' is similar at the individual and at the country level.

The interpretation of parameters in Bayesian CFA is identical to regular CFA models. Standardized factor loadings (see Figure 2) are sufficiently strong at the individual level (between 0.711 and 0.770 ) and country level (between 0.719 and 0.946 ). The strong loadings indicate that the domain-specific fears are, to a certain extent, expressions of a generalised fear or concern about European integration. At the individual level, different fears share between 51 percent (loss of social security) and 59 percent (loss of 
national identity and culture) of their variance with the general factor. At the same time, this finding implies that almost half of the variance of the domain-specific fears is not captured by the underlying factor. On top of the existence of a general component, citizens tend to differentiate between the various threats they perceive from European integration.

[Figure 2]

At the country level, the standardized factor loadings show a similar pattern but are slightly stronger (except for loss of jobs). Fear about a loss of social security loads 0.77 on the latent factor fear of European integration. About 59 percent of the variance in the fear about a loss of social security at the country level is shared with the general factor. The country averages for the five fears are more consistent compared with those of individuals. This indicates that spillover effects between different sources of Euroscepticism are more strongly operating at the country level. If, for example, the fear about a loss of social security provoked by European integration is extremely high in a certain country, it is likely that negative perceptions in other domains (political, cultural, financial and labour market) will also be very high. Nevertheless, Figure 3 illustrates that 
country means of fear about a loss of social security do not perfectly coincide with the other EU-related fears. We see for instance that the Irish and the British perceive lower levels of threat to social security than one would expect, given their average level of fear about European integration in other domains. ${ }^{4}$

[Figure 3]

Explaining citizens' fear about a loss of social security: Domain-specific

determinants?

To gain insight into the common and domain-specific determinants of various EUrelated concerns, we turn to MLSEM. Our model estimates individual-level and countrylevel effects on the latent variable 'fear of European integration' (thus representing the commonality of determinants) as well as on the domain-specific fears (i.e. the specific effects). ${ }^{5}$ The model includes a dummy variable for Latvia, which is an influential observation $^{6}$ (see the Online appendix). Table 2 shows the standardized estimates and 95 percent posterior probability intervals (PPI). PPI's should be interpreted as the 95 percent probability that in the population the parameter lies between the two values, while standardized parameters can be interpreted in the same way as regular regression 
coefficients. Fit indices based on robust maximum likelihood estimation indicate a good model fit $\left(\chi^{2}=594.618 ; d f=75 ; \mathrm{RMSEA}=0.013 ; \mathrm{CFI}=0.982 ; \mathrm{TLI}=0.968 ; \mathrm{SRMR}\right.$ within $=$ 0.006; SRMR between $=0.074)$.

\section{Generalised fear about European integration}

With regard to the individual level, several indicators of socioeconomic status have an effect on generalised fear over European integration (see Table 2). Those with a tertiary education report lower levels of generalised fear than those with lower educational credentials. Furthermore, income is negatively related to perceptions of feeling threatened by European integration. In comparison with those belonging to the highest income quartile, the other income groups report greater levels of fear. We observe subtle differences in fear about European integration depending on employment status: those who are in paid employment are more concerned about the consequences of European integration than pensioners and students are. Experiences of benefit dependence in the five years prior to the survey do not affect fear of European integration in general. Table 2 shows that citizens' ideological positions really matter in predicting fear of European integration. Those who are more strongly in favour of government intervention experience much higher levels of generalised fear about 
European integration. Additionally, individuals who support income redistribution to a larger extent also experience higher levels of threat concerning European integration. These findings support hypotheses $1 \mathrm{a}$ and $2 \mathrm{a}$. With regard to the control variables, Table 2 shows that women and citizens with anti-immigrant attitudes also report higher levels of generalised fear.

For the country level, we observe a positive effect of social spending on generalised fear, indicating that in member states where net spending on social protection benefits is higher, citizens are generally more concerned about the consequences of European integration. ${ }^{7}$ This confirms hypothesis $3 a$, stressing the relevance of national welfare arrangements on citizens' perceptions concerning European integration. Table 2 shows that the unemployment rate, the amount of net transfers received from the EU and the intra-EU immigration rate do not affect citizens' general threat perceptions. These findings indicate that national social protection is an important issue in understanding cross-national differences in the fear over European integration. Moreover, social protection outweighs contextual factors related to economic conditions, European transfers and immigration. Hypotheses $4 a-6 a$ are thus not supported.

The model explains 20.4 percent of the individual-level variance and 35.7 percent of the country-level variance in the generalised fear of European integration. 
Fear about a loss of social security resulting from European integration

Table 2 also includes the direct effects on the domain-specific fears of European integration. It shows that there are direct effects of some variables on citizens' fear of a loss of social security, in addition to the general pattern outlined above. Whereas high incomes are found to temper citizens' generalised fear of European integration, a person's income has an additional negative effect on the fear about the loss of social security. Concretely, those in the lowest two income quartiles are even more fearful regarding a loss of social security than one would expect based on their general score for fear about European integration. A lower income thus increases concerns about the EU's impact in the cultural, political, financial or economic sphere, but has an even more notable impact on the fear of a loss of social security. Similarly, employment status has an additional effect on fear about a loss of social security, on top of its effect on generalised fear of European integration. Students and pensioners report lower levels of generalised fear compared with the employed and these differences are even more pronounced regarding the perceived impact of the EU on social security. Those in paid employment might be very sensitive about potential changes in the social security system to which they contribute. Although the unemployed and disabled are not different from those in paid employment in terms of their general level of fear, they are more fearful than those in paid employment with regard to social security. The 
susceptibility to 'social Euroscepticism' among the unemployed and disabled can be explained by the direct interest in national welfare provision by these groups. Furthermore, dependence on means-tested social welfare benefits within the five years before the survey increases fear about a loss of social security, whereas benefit dependence does not affect the generalised fear level. These findings illustrate that indicators of socioeconomic status have a specific impact on fear of a loss of social security (hypothesis $1 \mathrm{~b}$ ). While utilitarian interest explains differences in generalised fear concerning European integration, this approach is even more important in explaining public concerns about the EU's impact on social security in particular.

Pro-state responsibility beliefs and support for income redistribution also have significant direct effects on social fears. These additional effects are positive, indicating that citizens who are in favour of strong welfare states are even more susceptible to social security related concerns about European integration than one would expect given their generalised fear of European integration. This confirms hypothesis $2 b$ and validates previous research stating that a left-wing orientation is positively associated with higher levels of fear about a loss of social security (Cautrès, 2012; Van Elsas and Van der Brug, 2015). Additionally, we find that the positive impact of anti-immigrant attitudes is weaker and that the gender gap is larger with regard to concerns about a loss of social security than about citizens' overall fear of European integration. 
Contrary to our expectations, we do not find domain-specific country-level explanations. While higher social spending increases generalised fears about the impact of European integration, it has no additional negative effect on fear concerning a loss of social security. Erosion of the social model by external influences is a big concern in advanced welfare states, which might cause European integration to be perceived not only as detrimental to social protection, but as a threatening process itself. In member states receiving more net transfers from the EU, citizens are not less fearful regarding European integration, nor are they more likely to evaluate the EU's impact on social protection positively than in member states receiving less. National economic conditions, measured by unemployment rates, do not affect citizens' generalised fear of European integration, nor influence citizens' evaluations of the EU's impact on social security. Lastly, in member states with higher proportions of EU immigrants, citizens are not more fearful about the consequences of European integration in any single domain. Hypotheses $3 b-6 b$ are thus not supported.

From these findings, we conclude that the uniqueness of different EU-related fears - in this case, the fear about a loss of social security - is reflected by the relevance of utilitarian and ideological factors as explanatory mechanisms. Concerns about the EU's impact on social security are generated by specific mechanisms at the individual level, namely citizens' dependence on the welfare state (being unemployed or disabled, and 
experience of means-tested benefit dependence) and positive attitudes towards the welfare state (pro-state responsibility and pro-income redistribution). At the country level, different EU-related fears overlap more strongly, which can explain why we do not find domain-specific mechanisms for concerns about a loss of social security. Euroscepticism at the country level is more a general phenomenon, whereas within countries, citizens differentiate between different EU-related fears. Although we also find significant additional effects on the other EU-related fears (columns 4-7 in Table 2), we do not discuss them, as they are beyond the scope of this article.

[Table 2]

\section{Conclusions}

Three major findings result from this study. First, Europeans are quite concerned about a loss of social security provoked by European integration, and this concern is not merely an expression of general anxiety about the European Union. Given that citizens are able to differentiate between particular fears indicates that they have a more sophisticated notion of European integration than is often suggested. Second, utilitarian and ideological determinants are of greater importance in explaining concerns about a loss 
of social security than in explaining generalised fear about European integration. Individuals with lower socioeconomic status and who are more in favour of strong welfare states are especially susceptible to 'social Euroscepticism'. These differential effects remain hidden when citizens' fear about a loss of social security is studied in isolation from other EU-related fears. Third, spillover effects between specific fears are stronger at the country level, which means that countries are characterised by a more general climate of fear about integration. This explains why we do not observe domainspecific contextual determinants of social security concerns. Citizens in member states with higher spending on social benefits are more fearful regarding European integration in general, although the effect of social spending is not stronger on fears about social security. A high level of social protection has the potential to function as a key catalyst for Euroscepticism, since the threat that integration poses to social welfare might be such a pervasive concern in these countries that it results in stronger reservations about European integration as such.

This study shows that fear regarding European integration is versatile. Research should continue to generate in-depth knowledge about which social groups have reservations concerning European integration and for what particular reason, in order to untangle specific types or sources of Euroscepticism. Citizens' concerns about specific consequences of European integration should ideally not be studied in isolation from 
other EU-related fears. Researchers should be aware that some of the explanatory mechanisms underlying a specific EU-related fear might be explained by citizens' generalised fear of European integration.

Some limitations and avenues for future research should be mentioned. First, our measurement of welfare beneficiaries is very rigorous, as it merely includes entitlements to means-tested welfare benefits. Therefore, the observed impact of welfare dependency on citizens' fear for a loss of social security may even be underestimated. Further, we did not include citizens' evaluations about the performance of their national welfare states. Citizens who think that their national welfare state is performing badly may perceive European integration as less threatening and perhaps as an opportunity to increase social protection. In addition, this study provides no insight into how concerns about the impact of European integration on social security are related to support for (further) European integration. Future research should examine how citizens' perceived impact of European integration on national welfare states facilitates or impedes their support for European social policy. So far, we assumed that citizens are able to evaluate how European integration potentially affects social security. In this regard, it remains unclear to what extent their evaluations are based on framing of the EU's performance by the media and national governments. Their practices of blaming the EU or giving credit to it may shape citizens' perceptions of the EU. Besides, 
our study does not provide insight into changes in individuals' fear of European integration over time and how recent incisive events at the European level may affect public perceptions. In this regard, since 2008, the Eurozone crisis and the recent refugee crisis may have stirred up citizens' threat perceptions. Depending on the degree to which countries were affected, these phenomena may have increased cross-national differences. For instance, in countries receiving financial assistance, European integration has potentially become strongly associated with cuts in social spending because of the austerity policies that were conditioned on the bailout packages. These issues remain unanswered and call for longitudinal or more recent cross-national data. In a broader sense, our results imply that European leaders cannot ignore the social agenda. Citizens are aware that European integration is no longer a unilateral story of economic affairs. How Europe can reconcile integration with social security has become an existential issue, not only for its popular legitimacy but also for its sustainability. European integration should proceed with explicit social objectives. Working towards upward convergence in social developments, without imposing a 'one-size-fits-all' model, would be an appropriate response to address concerns about the social consequences of integration. 


\section{Funding}

This study was made possible by grants from KU Leuven research council (OT/13/30) and the Research Foundation FWO - Flanders (Grant number G068816 N).

\section{Notes}

1. While it would be possible to elaborate on the differential impact of these predictors on the other domain-specific fears, this exercise is beyond the scope of this paper.

2. The samples from Great Britain and Northern Ireland were pooled to create one sample for the UK. This did not bias our findings.

3. This criterion determines convergence by considering within-chain and between-chain variability of the parameter estimates in terms of the potential scale reduction (Gelman et al., 2014).

4. Plotted country means of fear about a loss of social security with each of the other EU-related fears provide similar patterns; national identity $(B=0.84, p<0.001)$, power $(B=0.71, p<0.001)$, payments ( $B$ $=0.81, p<0.001)$ and jobs $(B=0.62, p<0.001)$.

5. Given that the analyses are conducted on a very large number of observations $(N=38,070)$, even miniscule and insubstantial effects quickly become statistically significant. Therefore, instead of solely relying on p-values, it is suggested to pay attention to effect sizes. Aiming for a parsimonious model, small unsubstantial direct effects were not allowed in the model.

6. Whereas higher levels of fear about European integration are found in countries with high social expenditure, Latvia does not fit this pattern as it combines low social expenditure with very high levels of fear.

7. We replaced social spending by average growth of GDP over the previous five years, to see whether the effect of social spending was due to economic wealth. This proved not to be the case. 
References

Abts K, Heerwegh D and Swyngedouw M (2009) Sources of Euroscepticism: Utilitarian Interest, Social Distrust, National Identity and Institutional Distrust. World Political Science Review 5(1): 1-26.

Andersen TM (2004) Challenges to the Scandinavian welfare model. European Journal of Political Economy 20(3): 743-754.

Anderson CJ and Kaltenhaler KC (1996) The Dynamics of Public Opinion toward European Integration, 1973-93. European Journal of International Relations 2(2): 175-199.

Anderson CJ and Reichert MS (1996) Economic Benefits and Support for Membership in the E.U.: A Cross-National Analysis. Journal of Public Policy 15(3): 231-249.

Anderson J (1995) Structural Funds and the Social Dimension of EU Policy: Springboard or Stumbling Block? In: Leibfried S and Pierson P (eds), European Social Policy. Between Integration and Fragmentation, Washington D.C.: The Brookings Institution, pp. 123-158.

Balestrini PP, Flood C and Flockton C (2010) National Public Opinion and the EU in the PostMaastricht Era: Is the Socialisation Theory Actually Dead? Journal of Contemporary European Studies 18(3): 377-400.

Beaudonnet L (2012) You Don't Bite The Hand That Feeds You: The Impact Of Redistribution On Attitudes Towards Europe. CSD Working Papers.

Beaudonnet L (2015) A Threatening Horizon: The Impact of the Welfare State on Support for Europe. Journal of Common Market Studies 53(3): 457-475.

Bechtel MM, Hainmueller J and Margalit Y (2014) Preferences for International Redistribution: The Divide over the Eurozone Bailouts. American Journal of Political Science 58(4): 835856.

Bernaciak M (2014) Social Dumping and the EU Integration Process. Brussels.

Bertoncini Y and Koenig N (2014) Euroscepticism or Europhobia: Voice vs. Exit? Notre Europe Policy Paper. http://www.delorsinstitute.eu/011-3003-Solidarity-within-the-EuropeanUnion-political-foundations.html (Accessed 27 November 2017).

Brinegar A and Jolly S (2005) Location, Location, Location: National Contextual Factors and Public Support for European Integration. European Union Politics 6(2): 155-180.

Burgoon B (2009) Social nation and social Europe: Support for national and supranational welfare compensation in Europe. European Union Politics 10(4): 427-455.

Carey S (2002) Undivided Loyalties: Is National Identity an Obstacle to European Integration? European Union Politics 3(4): 387-413.

Cautrès B (2012) Multidimensionality of EU attitudes in France: An issue for the Understanding 
of the Politicization of Attitudes Towards the EU. European Integration Online Papers 16(7): 1-28.

Cohn-Bendit D and Verhofstadt G (2012) Voor Europa! Antwerp: De Bezige Bij.

Delors J and Fernandes S (2013) Endowing the EMU with a Social Dimension. Notre Europe.

Eichenberg RC and Dalton RJ (2007) Post-Maastricht Blues: The Transformation of Citizen Support for European Integration, 1973-2004. Acta Politica 42(2): 128-152.

Eurofound (2014) Labour mobility in the EU: Recent trends and policies.

European Commission (1997) Standard Eurobarometer 46: Public Opinion in the European Union.

European Commission (2007) Standard Eurobarometer 65 / Spring 2006: Public Opinion in the European Union.

European Commission (2011) Standard Eurobarometer 76 / Autumn 2011: Public Opinion in the European Union.

European Commission (2015) EU budget 2014: Financial Report. Luxembourg.

EVS (2011) European Values Study 2008: Integrated Dataset (EVS 2008). GESIS Data Archive, Cologne. ZA4800 Data file version 3.0.0, doi: 10.4232/1.11004

Falkner G (2010) European Union. In: Castles FG, Leibfried S, Lewis J, et al. (eds), The Oxford Handbook of the Welfare State, Oxford: Oxford University Press, pp. 292-305.

Føllesdal A, Giorgi L and Heuberger R (2007) Envisioning European Solidarity between Welfare Ideologies and the European Social Agenda. Innovation 20(1): 75-89.

Foster C and Frieden J (2017) Crisis of trust: Socio-economic determinants of Europeans' confidence in government. European Union Politics 18(4): 511-535.

Fóti K (2015) 'Welfare Tourism' - An Unproven Case. Social Europe. Available from: https://www.socialeurope.eu/2015/12/welfare-tourism-unproven-case/ (Accessed 1 March 2016).

Gabel MJ (1998) Interests and Integration: Market Liberalization, Public Opinion, and European Union. Ann Arbor: University of Michigan Press.

Garry J and Tilley J (2015) Inequality, state ownership and the European Union: How economic context and economic ideology shape support for the European Union. European Union Politics 16(1): 139-154.

Gelman A, Carlin JB, Stern HS, et al. (2014) Bayesian Data Analysis. 3rd ed. Chapman \& Hall/CRC Press.

Gerhards J, Lengfeld H \& Häuberer J (2016) Do European citizens support the idea of a European welfare state? Evidence from a comparative survey conducted in three EU 
member states. International Sociology 31(6): 677-700.

Grauel J, Heine J and Lahusen C (2013) Who is Afraid of the (Big Bad) European Union? European Integration and Fears about Job Losses. In: Arts W and Halman L (eds), Value contrasts and Consensus in Present-Day Europe: Painting Europe's Moral Landscapes, Brill, pp. 19-43

Hobolt SB (2012) Public Opinion and Integration. In: Jones E, Menon A, and Weatherill S (eds), The Oxford Handbook of the European Union, Oxford: Oxford University Press, pp. 716733.

Hobolt SB (2015) Public attitudes towards the Euro Crisis. In: Cramme O and Hobolt SB (eds), Democratic Politics in a European Union Under Stress, Oxford: Oxford University Press, pp. 48-65.

Hooghe $L$ and Marks $G$ (1999) The Making of a Polity: The Struggle over European integration. In: Kitschelt $\mathrm{H}$, Lange $\mathrm{P}$, Marks $\mathrm{G}$, et al. (eds), Continuity and change in contemporary capitalism, Cambridge: Cambridge University Press, pp. 70-79.

Hooghe L and Marks G (2008) A Postfunctionalist Theory of European Integration: From Permissive Consensus to Constraining Dissensus. British Journal of Political Science 39(1): 1-23.

Hox J, van de Schoot R and Matthijsse S (2012) How few countries will do? Comparative survey analysis from a Bayesian perspective. Survey Research Methods 6(2): 87-93.

Karp JA and Bowler S (2006) Broadening and deepening or broadening versus deepening: The question of enlargement and Europe's 'hesitant Europeans'. European Journal of Political Research 45(3): 369-390.

Kriesi H, Grande E, Lachat R, et al. (2008) West European Politics in the Age of Globalization. Cambridge: Cambridge University Press.

Kvist J (2004) Does EU Enlargement Start a Race to the Bottom? Strategic Interaction among EU Member States in Social Policy. Journal of European Social Policy 14(3): 301-318.

Leconte C (2010) Understanding Euroscepticism. Palgrave Macmillan.

Lubbers M (2008) Regarding the Dutch 'Nee' to the European Constitution: A Test of the Identity, Utilitarian and Political Approaches to Voting 'No'. European Union Politics 9(1): 59-86.

McLaren L (2004) Opposition to European integration and fear of loss of national identity: Debunking a basic assumption regarding hostility to the integration project. European Journal of Political Research 43(6): 895-912.

Mau S (2005) Democratic Demand for a Social Europe? Preferences of the European Citizenry. International Journal of Social Welfare 14(2): 76-85.

Meuleman B and Billiet J (2009) A Monte Carlo sample size study: How many countries are 
needed for accurate multilevel SEM? Survey Research Methods 3(1): 45-58.

Netjes C (2004) All aboard? Explaining Public Support for European Integration in a postMaastricht Era. Paper presented for the panel 'Public Opinion and EU Enlargement' at the 2nd Pan-European Conference, Bologna, Italy, 24-26 June.

Ray L (2004) Don't Rock the Boat: Expectations, Fears, and Opposition to EU-level PolicyMaking. In: Marks G and Steenbergen M (eds), European Integration and Political Conflict, Cambridge: Cambridge University Press, pp. 51-61.

Sanchez-Cuenca I (2000) The Political Basis of Support for European Integration. European Union Politics 1(2): 147-171.

Scharpf FW (2010) The asymmetry of European integration, or why the EU cannot be a 'social market economy'. Socio-Economic Review 8(2): 211-250.

Scruggs, L, Detlef J and Kati K (2014). Comparative Welfare Entitlements Data Set 2, Version 2014-03. Available at: http://cwed2.org/ (Accessed 24 October 2017).

Serricchio F, Tsakatia M and Quaglia L (2013) Euroscepticism and the Global Financial Crisis. Journal of Common Market Studies 51(1): 51-64.

Sørensen C (2007) Euroscepticism: A Conceptual Analysis and a Longitudinal Cross-Country Examination of Public Scepticism Towards the European Union. University of Copenhagen.

Toshkov D and Kortenska E (2015) Does Immigration Undermine Public Support for Integration in the European Union? Journal of Common Market Studies 53(4): 910-925.

van Elsas E and van der Brug W (2015) The changing relationship between left-right ideology and euroscepticism, 1973-2010. European Union Politics 16(2): 194-215. 


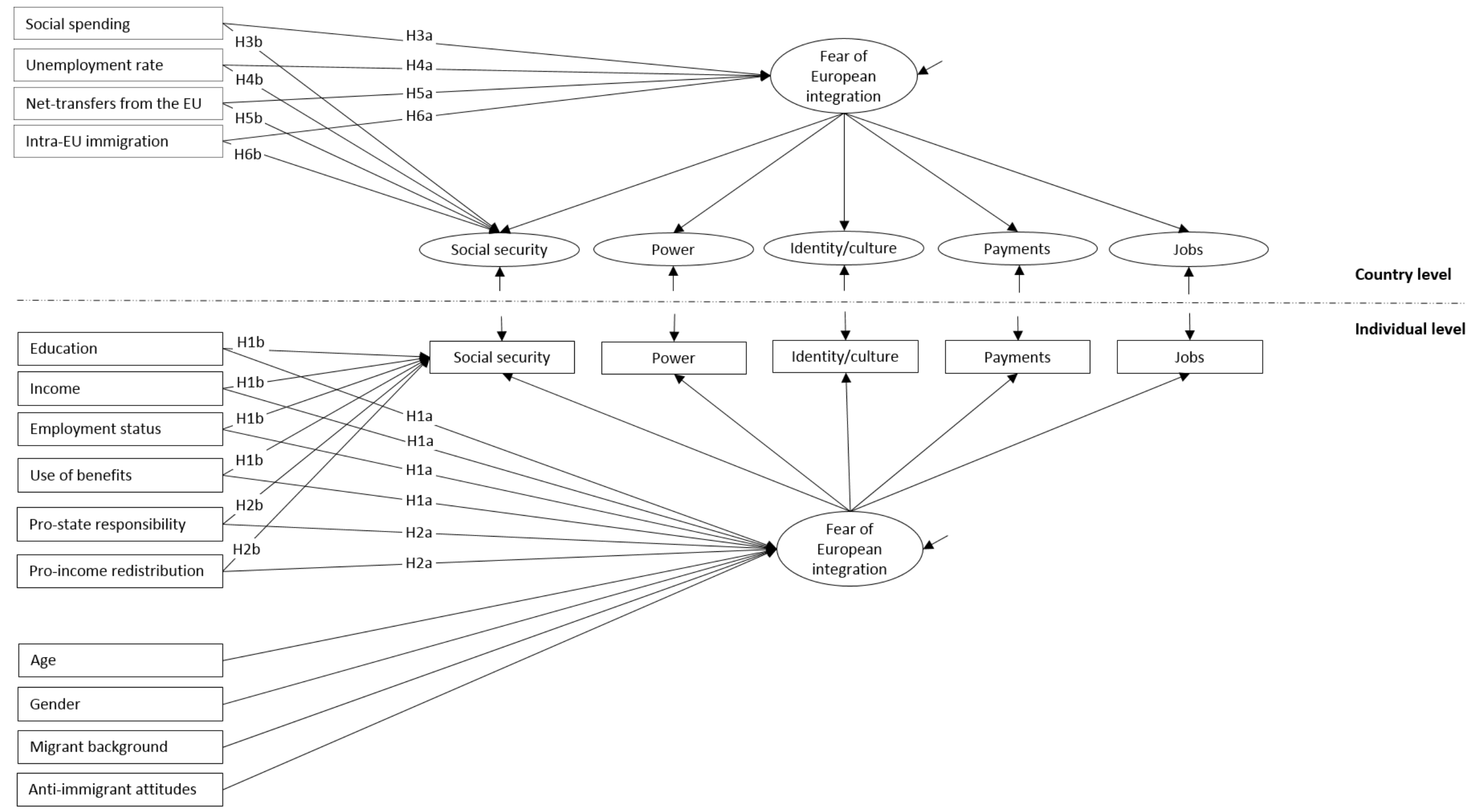

Figure 1. Hypothesized two-level structural equation model of citizens' fear of European integration 


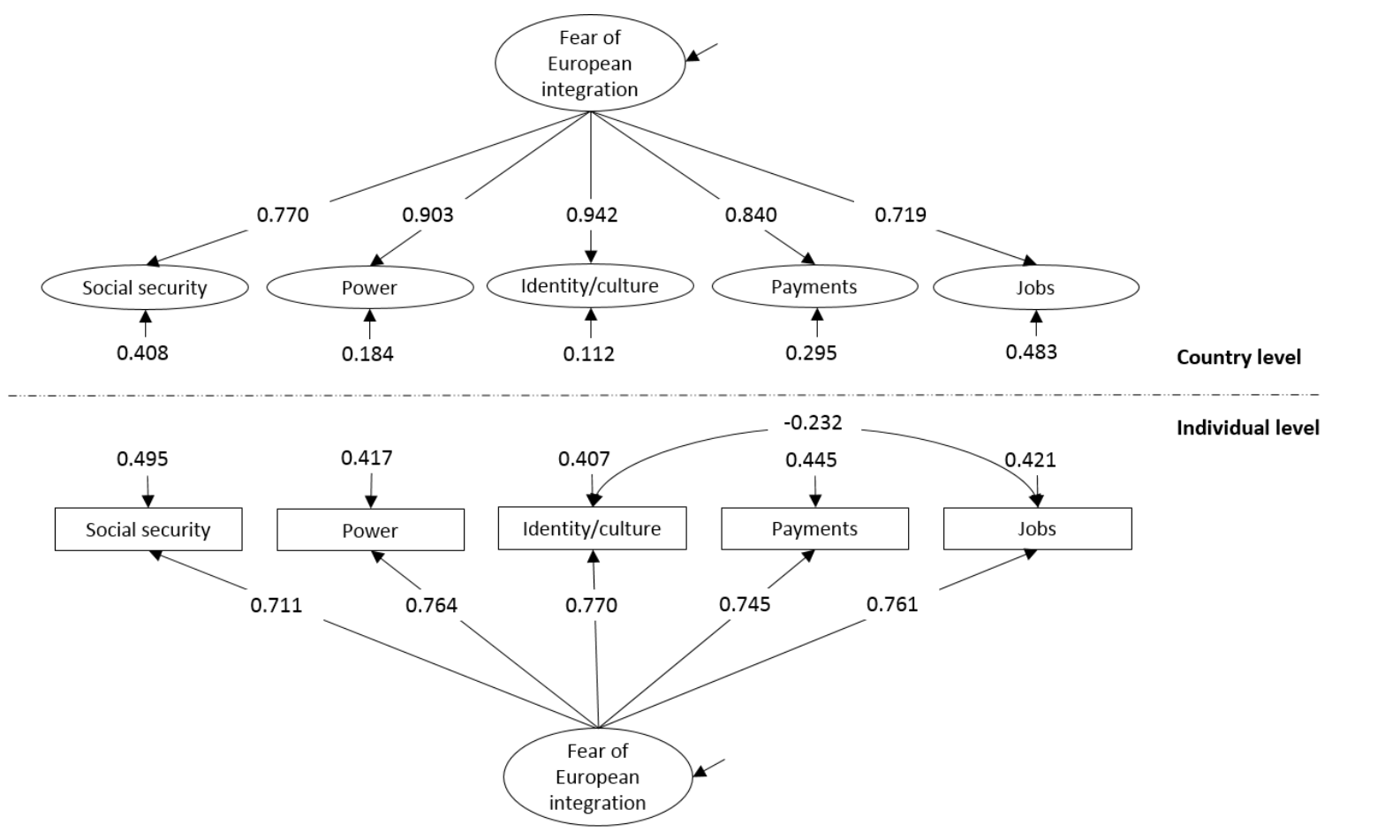

Figure 2. MLCFA model of citizens' fears of European integration - standardized parameters.

Note: $\mathrm{N}=40995 ;$ estimator $=$ Bayes; $\mathrm{PPP}=0.000 ; 95 \%$ confidence interval $=[810.950 ; 885.855])$. 


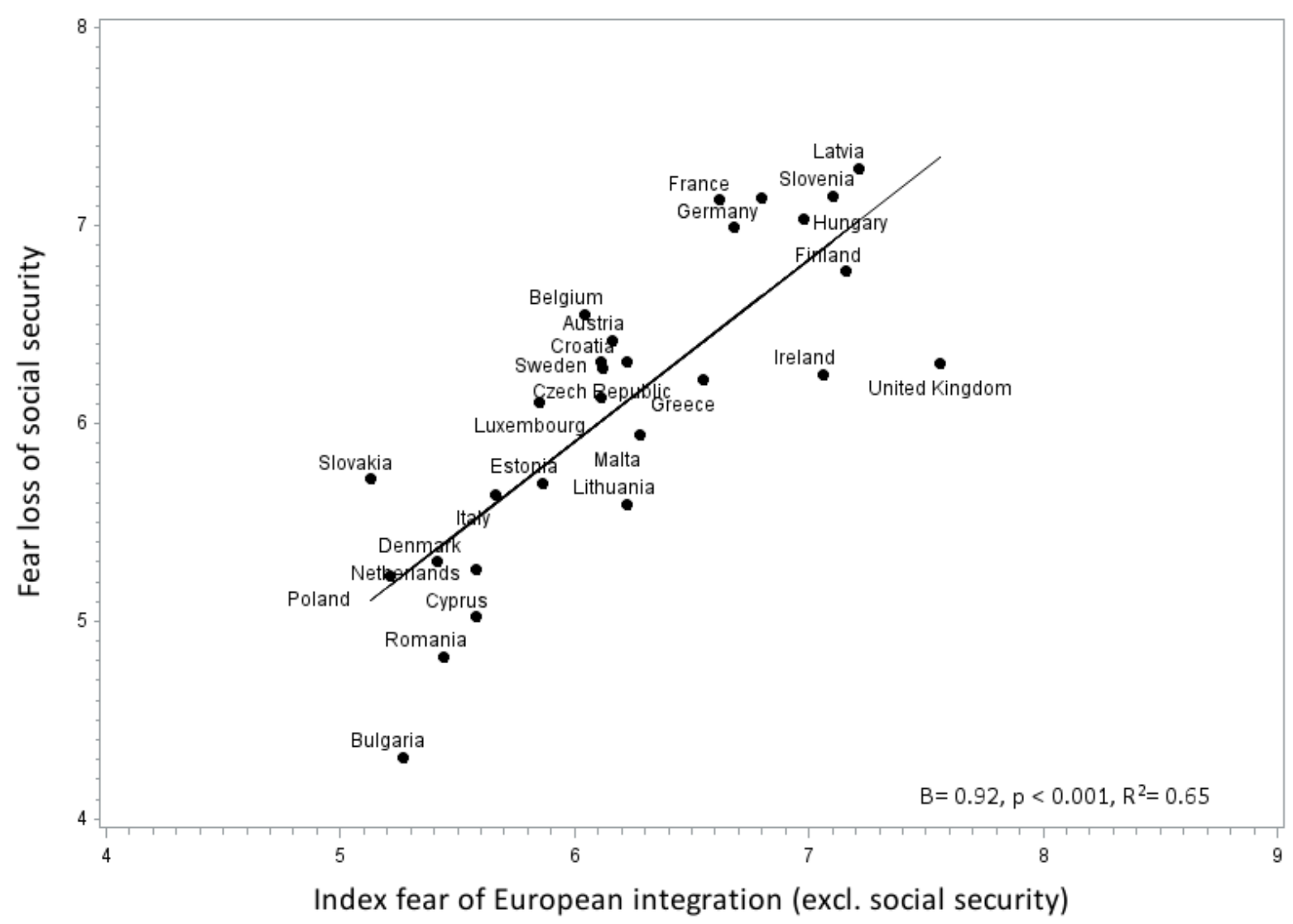

Figure 3. Scatterplot of country means for fear about European integration (loss of power, loss of national culture and identity, increasing payments, and loss of jobs) and mean fear about a loss of social security. 
Table 1. Hypotheses

\begin{tabular}{|c|c|c|}
\hline & General effect: fear about EU integration & Domain-specific effect: social security \\
\hline & $\begin{array}{l}\text { - Being in favour of state responsibility for } \\
\text { welfare and being in favour of income } \\
\text { redistribution is positively related to } \\
\text { generalised fear of European integration } \\
\text { (H2a). }\end{array}$ & $\begin{array}{l}\text { - On top of the effect of socioeconomic status } \\
\text { on generalised fear, indicators of } \\
\text { socioeconomic status have an additional } \\
\text { negative effect on fear for a loss of social } \\
\text { security (H1b). } \\
\text { On top of the effect of preferences for state } \\
\text { responsibility and income redistribution on } \\
\text { generalised fear, these preferences have an } \\
\text { additional positive effect on fear for a loss of } \\
\text { social security (H2b). }\end{array}$ \\
\hline & $\begin{array}{l}\text { - Where domestic social welfare provisions are } \\
\text { more extensive, generalised fear about } \\
\text { European integration is higher (H3a). } \\
\text { - Poor national economic conditions trigger } \\
\text { generalised fear of European integration } \\
\text { (H4a). } \\
\text { - Net transfers from the EU have a negative } \\
\text { effect on citizens' generalised fear of } \\
\text { European integration (H5a). } \\
\text { - High intra-European immigration rates have a } \\
\text { positive effect on citizens' generalised fear } \\
\text { about European integration (H6a) }\end{array}$ & $\begin{array}{l}\text { - On top of the effect of welfare provisions on } \\
\text { generalised fear, extensive welfare provisions } \\
\text { have an additional positive effect on fear for a } \\
\text { loss of social security (H3b). } \\
\text { On top of the effect of national economic } \\
\text { conditions on generalised fear, bad economic } \\
\text { conditions have an additional positive effect } \\
\text { on fear for a loss of social security (H4b). } \\
\text { On top of the effect of net EU-transfers on } \\
\text { generalised fear, net transfers have an } \\
\text { additional negative effect on fear for a loss of } \\
\text { social security (H5b). } \\
\text { On top of the effect of intra-EU immigration } \\
\text { on generalised fear, intra-EU immigration has } \\
\text { an additional positive effect on fear for a loss } \\
\text { of social security (H6b). }\end{array}$ \\
\hline
\end{tabular}


Table 2. Standardized parameter estimates and posterior probability intervals.

\begin{tabular}{|c|c|c|c|c|c|c|c|c|c|c|c|c|}
\hline & \multicolumn{2}{|c|}{ Generalised fear } & \multicolumn{2}{|c|}{ Social security } & \multicolumn{2}{|c|}{ Jobs } & \multicolumn{2}{|c|}{ Culture } & \multicolumn{2}{|c|}{ Payments } & \multicolumn{2}{|c|}{ Power } \\
\hline & Estimate & $95 \% \mathrm{PPI}$ & Estimate & $95 \% \mathrm{PPI}$ & Estimate & $95 \% \mathrm{PPI}$ & Estimate & $95 \% \mathrm{PPI}$ & Estimate & $95 \% \mathrm{PPI}$ & Estimate & $95 \% \mathrm{PPI}$ \\
\hline \multicolumn{13}{|l|}{ INDIVIDUAL LEVEL } \\
\hline & -0.008 & {$[-0.023 ; 0.007]$} & & & & & & & & & & \\
\hline $\begin{array}{l}\text { Gender }(\text { ref = male }) \\
\text { Education }\end{array}$ & $0.061^{*}$ & {$[0.051 ; 0.071]$} & $0.019^{*}$ & {$[0.011 ; 0.027]$} & & & & & & & & \\
\hline Lower-secondary & $0.131^{*}$ & {$[0.116 ; 0.146]$} & & & $0.030^{*}$ & {$[0.019 ; 0.041]$} & $-0.038^{*}$ & {$[-0.049 ;-0.027]$} & & & & \\
\hline Upper-secondary & $0.109^{*}$ & {$[0.095 ; 0.124]$} & & & $0.026^{*}$ & {$[0.015 ; 0.036]$} & $-0.019^{*}$ & {$[-0.029 ;-0.008]$} & & & & \\
\hline \multirow{2}{*}{\multicolumn{13}{|c|}{$\begin{array}{l}\text { Tertiary (ref) } \\
\text { Income }\end{array}$}} \\
\hline & & & & & & & & & & & & \\
\hline $1^{\text {st }}$ quartile & $0.068^{*}$ & {$[0.053 ; 0.082]$} & $0.018^{\star}$ & {$[0.006 ; 0.028]$} & & & $-0.029^{\star}$ & {$[-0.039 ;-0.017]$} & & & & \\
\hline $2^{\text {nd }}$ quartile & $0.065^{*}$ & {$[0.051 ; 0.079]$} & $0.016^{*}$ & {$[0.005 ; 0.026]$} & & & $-0.017^{*}$ & {$[-0.027 ;-0.006]$} & & & & \\
\hline $3^{\text {rd }}$ quartile & $0.035^{*}$ & {$[0.022 ; 0.049]$} & 0.008 & {$[-0.002 ; 0.018]$} & & & $-0.019^{*}$ & {$[-0.029 ;-0.009]$} & & & & \\
\hline $4^{\text {th }}$ quartile (ref) & & & & & & & & & & & & \\
\hline Missing & $0.048^{\star}$ & {$[0.034 ; 0.062]$} & $0.010^{*}$ & {$[-0.001 ; 0.020]$} & & & -0.009 & {$[-0.019 ; 0.002]$} & & & & \\
\hline \multicolumn{13}{|l|}{$\begin{array}{l}\text { Employment status } \\
\text { Paid employment (ref) }\end{array}$} \\
\hline Pensioned & $-0.018^{*}$ & {$[-0.033 ;-0.003]$} & $-0.028^{*}$ & {$[-0.036 ;-0.019]$} & & & & & & & & \\
\hline Student & $-0.031^{*}$ & {$[-0.042 ;-0.020]$} & $-0.009^{*}$ & {$[-0.017 ;-0.001]$} & & & & & & & & \\
\hline Unemployed/disabled & 0.003 & {$[-0.008 ; 0.014]$} & $0.009^{*}$ & {$[0.001 ; 0.018]$} & & & & & & & & \\
\hline Others & -0.008 & {$[-0.019 ; 0.003]$} & -0.008 & {$[-0.016 ; 0.001]$} & & & & & & & & \\
\hline Dependence on welfare & 0.009 & {$[-0.002 ; 0.019]$} & $0.030^{*}$ & {$[0.022-0.038]$} & & & & & & & & \\
\hline \multicolumn{13}{|l|}{$\begin{array}{l}\text { benefits over previous } \\
\text { five years }\end{array}$} \\
\hline Pro-state responsibility & $0.092^{*}$ & {$[0.081 ; 0.102]$} & $0.034^{*}$ & {$[0.026 ; 0.042]$} & & & $-0.027^{\star}$ & {$[-0.035 ;-0.019]$} & & & & \\
\hline Pro-income & $0.059^{*}$ & {$[0.048 ; 0.069]$} & $0.039^{*}$ & {$[0.030 ; 0.047]$} & & & & & $-0.022^{*}$ & {$[-0.031 ;-0.014]$} & & \\
\hline $\begin{array}{l}\text { redistribution } \\
\text { Anti-immigrant attitude }\end{array}$ & $0.379^{*}$ & {$[0.370 ; 0.390]$} & $-0.049^{*}$ & {$[-0.059 ;-0.040]$} & $0.019^{*}$ & {$[0.009 ; 0.028]$} & & & & & & \\
\hline Migration background & -0.005 & {$[-0.016 ; 0.007]$} & & & $0.028^{*}$ & {$[0.020 ; 0.036]$} & $-0.020^{\star}$ & {$[-0.028 ;-0.011]$} & & & & \\
\hline \multicolumn{13}{|l|}{ COUNTRY LEVEL } \\
\hline Unemployment rate & 0.115 & {$[-0.213 ; 0.428]$} & & & & & & & & & & \\
\hline Spending on social & $0.507^{\star}$ & {$[0.083 ; 0.808]$} & & & & & & & & & & \\
\hline Transfers received from & 0.070 & {$[-0.334 ; 0.474]$} & & & & & & & & & & \\
\hline $\begin{array}{l}\text { EU (\% of GDP) } \\
\text { EU immigrants (per }\end{array}$ & 0.064 & {$[-0.269 ; 0.372]$} & & & & & & & & & & \\
\hline $\begin{array}{l}1000 \text { inhabitants) } \\
\text { Dummy Latvia }\end{array}$ & 0365 & 10011.06301 & & & & & & & & & & \\
\hline \multirow{2}{*}{\multicolumn{13}{|c|}{ Residual covariance }} \\
\hline & & & & & & & & & & & & \\
\hline Fearjobs with fearcult & $-0.233^{*}$ & {$[-0.249 ;-0.218]$} & & & & & & & & & & \\
\hline $\mathbf{R}^{2}$ individual level & $0.204^{*}$ & {$[0.196 ; 0.213]$} & 0.517 & {$[0.508 ; 0.525]$} & 0.587 & {$[0.578 ; 0.595]$} & 0.596 & {$[0.587 ; 0.605]$} & 0.554 & {$[0.546 ; 0.563]$} & 0.581 & {$[0.573 ; 0.589]$} \\
\hline $\mathbf{R}^{2}$ country level & $0.357^{\star}$ & {$[0.121 ; 0.579]$} & 0.715 & {$[0.505 ; 0.869]$} & 0.617 & {$[0.399 ; 0.800]$} & 0.883 & {$[0.716 ; 0.972]$} & 0.763 & {$[0.558 ; 0.896]$} & 0.827 & {$[0.631 ; 0.934]$} \\
\hline
\end{tabular}


Online appendix

Table A1. Descriptive statistics of individual-level variables.

\begin{tabular}{|c|c|c|c|c|}
\hline & Mean / \% & S.D. & $\begin{array}{l}\text { Cronbach's } \\
\text { alpha }\end{array}$ & $\mathrm{N}$ \\
\hline DEPENDENT VARIABLES & & & 0.87 & \\
\hline Fear loss of social security & 6.18 & 3.03 & & 39927 \\
\hline Fear loss of power & 5.70 & 3.02 & & 39268 \\
\hline Fear loss of national identity and culture & 5.74 & 3.07 & & 40259 \\
\hline Fear payments & 6.72 & 2.81 & & 39182 \\
\hline Fear loss of jobs & 6.82 & 3.00 & & 40292 \\
\hline \multicolumn{5}{|l|}{ INDEPENDENT VARIABLES AND CONTROLS } \\
\hline Age & 48.60 & 18.04 & & 41799 \\
\hline Gender & & & & 41974 \\
\hline Man & $44 \%$ & & & \\
\hline Woman & $56 \%$ & & & \\
\hline Educational level & & & & 41570 \\
\hline Lower-secondary & $33.34 \%$ & & & \\
\hline Upper-secondary & $44.65 \%$ & & & \\
\hline Tertiary & $22.01 \%$ & & & \\
\hline Income & & & & 41982 \\
\hline First quartile & $20.14 \%$ & & & \\
\hline Second quartile & $17.66 \%$ & & & \\
\hline Third quartile & $18.48 \%$ & & & \\
\hline Fourth quartile & $18.64 \%$ & & & \\
\hline Missing & $25.09 \%$ & & & \\
\hline Employment status & & & & 41690 \\
\hline Paid employment & $52.32 \%$ & & & \\
\hline Retired & $25.79 \%$ & & & \\
\hline Student & $5.79 \%$ & & & \\
\hline Unemployed or disabled & $7.46 \%$ & & & \\
\hline Other & $8.64 \%$ & & & \\
\hline Use of benefits & & & & 41273 \\
\hline No & $86.61 \%$ & & & \\
\hline Yes & $13.39 \%$ & & & \\
\hline Pro-state responsibility & 4.81 & 2.61 & & 41141 \\
\hline Pro-income redistribution & 5.80 & 2.81 & & 40709 \\
\hline Migration background & & & & 41616 \\
\hline No & $85.39 \%$ & & & \\
\hline Yes & $14.61 \%$ & & & \\
\hline Anti-immigrant attitudes & 6.17 & 2.24 & 0.87 & 41461 \\
\hline
\end{tabular}


Table A2. Overview of country-level characteristics in 2008.

\begin{tabular}{|c|c|c|c|c|c|c|}
\hline Country & Survey year & $\mathbf{N}$ & $\begin{array}{l}\text { Net social } \\
\text { spending (\% } \\
\text { GDP) }\end{array}$ & $\begin{array}{l}\text { Unemploy- } \\
\text { ment rate }\end{array}$ & $\begin{array}{l}\text { Net } \\
\text { transfers EU } \\
\text { (\% GNI) }\end{array}$ & $\begin{array}{l}\text { Intra-EU } \\
\text { immigration } \\
\text { (/ } 1000 \text { inh.) }\end{array}$ \\
\hline Austria & 2008 & 1510 & 24.80 & 4.1 & -0.12 & 34.44 \\
\hline Belgium & 2009 & 1509 & 24.37 & 7.0 & -0.20 & 61.82 \\
\hline Bulgaria & 2008 & 1500 & 14.95 & 5.6 & 1.92 & 1.01 \\
\hline Croatia & 2008 & 1525 & 17.94 & 8.6 & 0.29 & 1.76 \\
\hline Cyprus & 2008 & 1000 & 18.32 & 3.7 & -0.10 & 103.01 \\
\hline Czech Republic & 2008 & 1821 & 17.42 & 4.4 & 0.78 & 12.67 \\
\hline Denmark & 2008 & 1507 & 24.59 & 3.4 & -0.22 & 17.01 \\
\hline Estonia & 2008 & 1518 & 14.74 & 5.5 & 1.46 & 6.19 \\
\hline Finland & 2009 & 1134 & 22.80 & 6.4 & -0.16 & 8.90 \\
\hline France & 2008 & 1501 & $30.06^{c}$ & 7.4 & -0.19 & 20.15 \\
\hline Germany & $2008-2009$ & 2075 & 24.88 & 7.4 & -0.34 & 30.60 \\
\hline Greece & 2008 & 1500 & 24.30 & 7.8 & 2.68 & 14.12 \\
\hline Hungary & $2008-2009$ & 1513 & 22.15 & 7.8 & 1.11 & 10.04 \\
\hline Ireland & 2008 & 1011 & 19.97 & 6.4 & 0.35 & 90.44 \\
\hline Italy & 2009 & 1519 & 23.64 & 6.7 & -0.25 & 15.67 \\
\hline Latvia & 2008 & 1506 & 12.21 & 7.7 & 1.69 & 2.30 \\
\hline Lithuania & 2008 & 1500 & 15.25 & 5.8 & 2.67 & 1.05 \\
\hline Luxembourg & 2008 & 1610 & 19.48 & 4.9 & -0.07 & 365.89 \\
\hline Malta & 2008 & 1500 & 17.56 & 6.0 & 0.50 & 19.96 \\
\hline The Netherlands & 2008 & 1553 & 21.93 & 3.7 & -0.43 & 16.03 \\
\hline Poland & 2008 & 1510 & $16.94^{c}$ & 7.1 & 1.25 & 0.66 \\
\hline Portugal & 2008 & 1553 & 22.53 & 8.8 & 1.57 & 10.91 \\
\hline Romania & 2008 & 1489 & 14.07 & 5.6 & 1.14 & 0.28 \\
\hline Slovak Republic & 2008 & 1509 & 15.53 & 9.6 & 1.13 & 4.80 \\
\hline Slovenia & 2008 & 1366 & 20.65 & 4.4 & 0.31 & 2.03 \\
\hline Spain & 2008 & 1500 & 20.68 & 11.3 & 0.26 & 46.65 \\
\hline Sweden & $2009-2010$ & 1187 & 24.99 & 6.2 & -0.40 & 26.24 \\
\hline \multirow[t]{2}{*}{ United Kingdom } & $2009-2010^{\mathrm{a}}$ & 2056 & 22.46 & 5.6 & -0.04 & 26.40 \\
\hline & $/ 2008^{b}$ & & & & & \\
\hline
\end{tabular}

$a=$ Great Britain; $b=$ Northern Ireland; c= figures from 2010; Source: Eurostat. 


\section{Country means of domain-specific fears about European integration}

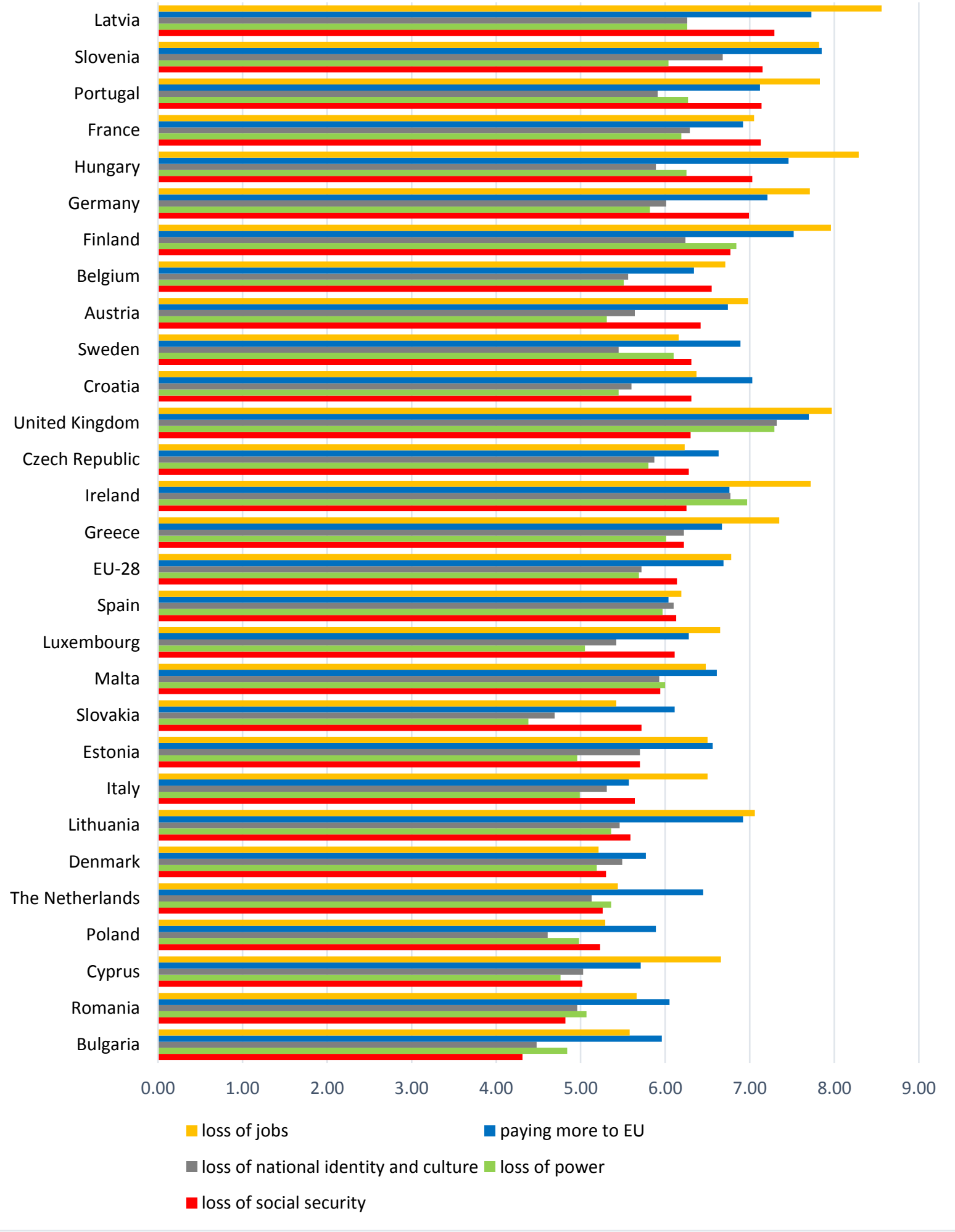

Figure A1. EU-28 and country means for fear about European integration (weighted for gender and age) Source: EVS 2008, own calculations. 
Figure A1 shows the country averages for the five domain-specific fears (sorted by the level of fear about a loss of social security). In Latvia, Slovenia, Portugal and France, citizens view the EU's impact on social security most negatively (>7). The group of countries where average social fear is higher than the EU average is very diverse. There is no notable divide between European populations that express more concerns about European integration in general, and countries where citizens are more positive overall. Instead, the country ranking diverges to a large extent according to the specific issue that is considered. In the UK for example, concerns about shrinking national power are the highest out of all the member states, whereas the average fear about a loss of social security is close to the EU average. This suggests that the domain-specific fears originate, to a certain extent at least, along idiosyncratic lines. 


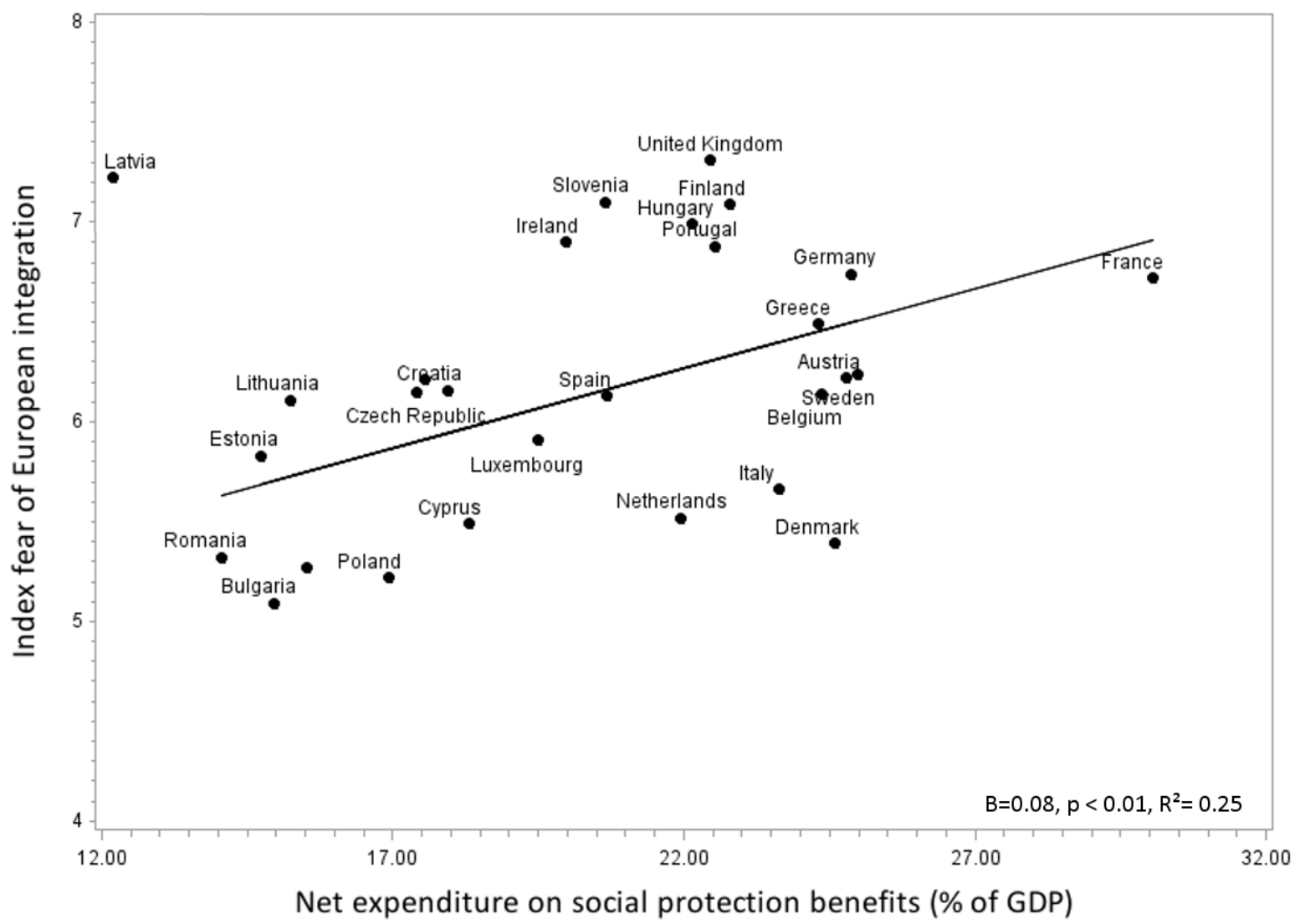

Figure A2. Scatterplot of country's social spending and mean fear of European integration.

Note: Latvia is not included in the estimation of the trend line 